$\mathrm{K}$

STUDIA Z PRAWA WYZNANIOWEGO

Tom $23-2020$

DOI: https://doi.org/10.31743/spw.9697

\author{
MARK HILL QC
}

\title{
THE QUALIFIED RIGHT TO FREEDOM OF RELIGION: AN EXAMINATION OF THE LIMITATIONS CONTAINED IN ARTICLE 9 OF THE EUROPEAN CONVENTION ON HUMAN RIGHTS
}

\begin{abstract}
The manifestation of religious beliefs under Article 9 of the European Convention on Human Rights is not absolute but may be subject to prescribed limitations. This article discusses the nature and extent of those limitations, as interpreted in the case law of the European Court of Human Rights from its decision in Kokkinakis v. Greece up to the present. It contrasts the prescriptive text of the Article with its loose and inconsistent interpretation by the Court in Strasbourg. Particular attention is given to the criteria of 'prescribed by law', 'necessary in a democratic society', 'public safety', 'public order, health or morals' and 'the rights and freedoms of others'. This article seeks to extract clear principles from the contradictory and confusing jurisprudence, particularly at its intersection with the Court's illusory doctrine of margin of appreciation.

Key words: Kokkinakis; freedom of religion; Article 9; limitations; public order; rights and freedoms of others; prescribed by law; necessary in a democratic society; margin of appreciation; European Court of Human Rights; European Convention on Human Rights
\end{abstract}

An earlier version if this chapter appeared in Temperman et al. (eds), The European Court of Human Rights and the Freedom of Religion or Belief (Brill Nijhoff, Leiden, 2019). I am grateful to Michael Brett for his assistance in additional research and drafting.

* Associate Professor at the Centre for Law and Religion, Cardiff University, Wales; King's College, London University, United Kingdom; Pretoria University, South Africa; Notre Dame University, Sydney, Australia; Lecturer in Law, Open University, United Kingdom; e-mail: Mark.Hill@ftbchambers.co.uk. ORCID 0000-0001-9614-8349. 


\section{INTRODUCTION}

In common with most qualified rights contained in the European Convention on Human Rights (the Convention), the first part of Article 9 sets out the content of the right while the second part specifies the grounds on which the right may lawfully be limited:

1. Everyone has the right to freedom of thought, conscience and religion; this right includes freedom to change his religion or belief and freedom, either alone or in community with others and in public or private, to manifest his religion or belief, in worship, teaching, practice and observance.

2. Freedom to manifest one's religion or beliefs shall be subject only to such limitations as are prescribed by law and are necessary in a democratic society in the interests of public safety, for the protection of public order, health or morals, or for the protection of the rights and freedoms of others.

Article 9(1) has been interpreted by the European Court of $\mathrm{Hu}-$ man Rights (the Court) to contain an 'internal' and an 'external' aspect. ${ }^{1}$ The "internal'" aspect of Article 9, the right to freedom of thought, conscience and religion, is an absolute right such that it may not be restricted. ${ }^{3}$ In contrast, the 'external' 4 aspect of Article 9, the right to manifest a 'religion or belief' in 'worship, teaching, practice and observance', is subject to the limitations in Article 9(2). ${ }^{5}$ This article examines the approach of the Court to these restrictions with a particular focus on their inter-relationship with the judicial deployment of the so-called margin of appreciation.

1 See, for example, Evans 1997; Bratza 2012, 9-26.

2 Also known as the forum internum.

3 Darby v. Sweden, 9 May 1989, European Commission on Human Rights, Application No. 11581/85, para. 44

4 Also known as the forum externum.

5 A State is permitted to derogate from its obligations under Article 9 '[i]n time of war or other public emergency threatening the life of the nation' as permitted by Article 15 . 


\section{THE STRUCTURE OF ARTICLE 9}

In determining whether there has been a breach of Article 9, the Court has developed a methodology which consists of addressing, sequentially, the following questions:

(i) Does the complaint fall within the scope of Article 9?

(ii) Has there been any interference with Article 9 rights?

(iii) Is the limitation on manifestation of religion or belief 'prescribed by law'?

(iv) Is the limitation on the manifestation of religion or belief in pursuit of a 'legitimate aim'?

(v) Is the limitation on manifestation of religion or belief "necessary in a democratic society'?

The burden of proof in respect of questions (i) and (ii) lies on the individual applicant and only if they are both answered in the affirmative will the Court will proceed to consider the issue of justification. For an interference with the manifestation of religion or belief to be justified, and therefore lawful, the Court must consider questions (iii), (iv) and (v). Here the burden of proof shifts to the government of the respondent State. Only if all three questions are resolved in favour of the State party will the application be dismissed. If the Court is not satisfied on these three questions, then there will be a violation of Article 9.

The internal aspect of Article 9, namely the absolute freedom to believe what one wishes, is self-evidently not the concern of the State, thus the vast preponderance of applications which reach the Court concern the external aspect. To fall within the scope of Article 9, applicants must establish that their complaint concerns the manifestation of a religion or belief. In Eweida v. United Kingdom the Court explained this concept as follows:

The right to freedom of thought, conscience and religion denotes views that attain a certain level of cogency, seriousness, cohesion and importance. Provided this is satisfied, the State's duty of neutrality and impartiality is incompatible with any power on the State's part to assess the legitimacy of religious beliefs or the ways in which those beliefs are expressed. 
Even where the belief in question attains the required level of cogency and importance, it cannot be said that every act which is in some way inspired, motivated or influenced by it constitutes a 'manifestation' of the belief. Thus, for example, acts or omissions which do not directly express the belief concerned or which are only remotely connected to a precept of faith fall outside the protection of art.9(2). In order to count as a 'manifestation' within the meaning of Article 9, the act in question must be intimately linked to the religion or belief. An example would be an act of worship or devotion which forms part of the practice of a religion or belief in a generally recognised form. However, the manifestation of religion or belief is not limited to such acts; the existence of a sufficiently close and direct nexus between the act and the underlying belief must be determined on the facts of each case. ${ }^{6}$

Once it has been established that the complaint falls within the scope of Article 9, the applicant must demonstrate that there has been an 'interference' with his Article 9 rights. An 'interference' usually constitutes conduct by a State (such as a prohibition or restriction on certain conduct) which prevents or inhibits religiously motivated practices. However, interference may also involve a State failing to take necessary action in circumstances where positive obligations arise.

The distinction between the internal/belief/unqualified element and the external/manifestation/qualified element of Article 9 is not always fully comprehended by the Court. For example, the Court recently considered breaches of both Article 9(1) and 9(2) in Mockute v. Lithuania. ${ }^{7}$ A woman who had been forcibly detained on grounds of psychiatric disorder, complained that doctors attempted to force her to alter her adherence to and respect for a system of spiritual meditation to which she had become attached (which would be a violation of the internal element) and that the restrictive regime of the psychiatric hospital prevented her from manifesting her belief (the external element). The Court found for the applicant, holding that 'pressure was exerted on her to change her religious beliefs and prevent her from manifesting them' ${ }^{8}$ It went on, unnecessarily, to consider the Article 9(2) test in respect of both violations, finding them

6 Eweida v. United Kingdom, 15 January 2013, European Court of Human Rights, Application Nos. 48420/10, 59842/10, 51671/10 and 36516/10, paras. 81-82. For a discussion of the judgment, see Hill 2013, 191-203.

7 Mockute v. Lithuania, 27 May 2019, European Court of Human Rights, Application No.66490/09.

$8 \quad$ Ibid. para. 123. 
not to be 'prescribed by law'. ${ }^{9}$ This judgment demonstrates some confusion about the structure and character of Article 9 on the part of judges far more familiar perhaps with Article 9(2) than Article 9(1). It was unnecessary to address the justifications in Article 9(2) under the first complaint in Mockutë's as a breach of Article 9(1) as found, is not subject to the limitation provisions of Article 9(2).

\section{LIMITATION ARGUMENTS IN KOKKINAKIS}

The benchmark case for the justification of interference with the manifestation of belief under Article 9(2) is Kokkinakis v. Greece. ${ }^{10}$ The applicant was a Greek national and Jehovah's Witness who was invited into an Orthodox Christian's home. He was subsequently arrested, tried, convicted and fined for proselytism contrary to Greek law. Amongst other matters, the applicant complained that this treatment was contrary to Article 9.

The Government's argument in response was that religious adherents in Greece enjoyed the right to express their beliefs freely and to try to influence the beliefs of others, Christian witness being a duty of all churches and all Christians. It was said, however, that there was an important distinction between bearing witness and improper proselytism, which involved the use of deceitful, unworthy and immoral means. It was this kind of proselytism which the Greek law in question was designed to prevent.

In its judgment the Court began by identifying the rationale for the legitimate limitations imposed on the Article 9 right:

[I]n democratic societies, in which several religions coexist within one and the same population, it may be necessary to place restrictions on this freedom in order to reconcile the interests of the various groups and ensure that everyone's beliefs are respected. ${ }^{11}$

$9 \quad$ Ibid. paras. 127-131.

10 Kokkinakis v. Greece, 25 May 1993, European Court of Human Rights, Application No. 14307/88.

11 Ibid., para. 33. 
In respect of whether the impugned provision of Greek criminal law was 'prescribed by law', the Court rejected the applicant's contention that the offence was insufficiently defined. It recognised that statutes are often couched in relatively vague terms so that they remain applicable to changing circumstances. In this case the necessary clarity was provided by a body of settled national jurisprudence. ${ }^{12}$

The Government went on to argue that ensuring the peaceful enjoyment of the personal freedoms of others, specifically by protecting 'a person's religious beliefs and dignity from attempts to influence them by immoral and deceitful means', was a legitimate aim. ${ }^{13}$ The Court broadly agreed with this submission, finding that the measure was in pursuit of a legitimate aim under Article 9(2), "namely the protection of the rights and freedoms of others'. ${ }^{14}$

The Court addressed the 'necessary in a democratic society' test in greater detail. The analysis began with a recognition that States have a 'certain margin of appreciation' in assessing the extent to which an interference is justified, and that in this context the Court's task is to determine 'whether the measures taken at national level were justified in principle and proportionate'. ${ }^{15}$ In order to do this 'the Court must look at the impugned judicial decisions against the background of the case as a whole'. ${ }^{16}$

The Court accepted that there was distinction between bearing Christian witness and improper proselytism. The former was said to be a key element of Christianity while the latter, described as involving the exertion of improper pressure on people in distress or in need, was a 'corruption or deformation' of the former and incompatible with respect for the freedom of thought, conscience and religion of others. ${ }^{17}$

On this basis the Court accepted that the impugned measure was acceptable in so far as it was designed to punish improper proselytism. However, it went on to find a violation of Article 9 because the Greek courts had not explained properly the reasons for which the applicant's

12 Ibid., para. 40.

13 Ibid., para. 42.

14 Ibid., para. 44.

15 Ibid., para. 47.

16 Ibid.

17 Ibid., para. 48. 
proselytism had been deemed 'improper' - all the courts had done was to reiterate the wording of the relevant provision of the Greek criminal law. Therefore, the Greek government had failed to show that the applicant's conviction was justified in the circumstances of the case by a pressing social need.

\section{LIMITATION ARGUMENTS IN SUBSEQUENT CASES}

The use of limitation arguments in subsequent cases have followed closely the text of Article 9(2), so it is helpful to address them sequentially adopting the language of the Convention.

\subsection{PRESCRIBED BY LAW}

The requirement that an interference must be 'prescribed by law' is not unique to Article 9(2) but is found also in Articles 8(2), 10(2) and 11(2). ${ }^{18}$ The Court has interpreted this to mean that, first, the interference must be grounded in national law. ${ }^{19}$ Secondly, the law in question must be 'adequately accessible' and thirdly, it must be 'formulated with sufficient precision to enable the citizen to regulate his conduct' ${ }^{20}$ Fourthly, the law must provide for arbitrariness or excessive discretion. As explained in Gillan v. United Kingdom, the law:

must afford a measure of legal protection against arbitrary interferences by public authorities with the rights safeguarded by the Convention. In matters affecting

18 The requirement in Article 8(2) is worded differently, 'in accordance with law', but has the same meaning as 'prescribed by law': Sunday Times v. United Kingdom, 26 April 1979, European Court of Human Rights, No. 6538/74, para. 48 (the French text of the ECHR provides 'prevue(s) par la loi' in all cases).

19 Djavit An v. Turkey, 20 February 2003, European Court of Human Rights, Application No. 20652/92, para. 67.

20 Sunday Times v. United Kingdom, 26 April 1979, European Court of Human Rights, Application No. 6538/74, para. 49. 
fundamental rights it would be contrary to the rule of law [...] for a legal discretion granted to the executive to be expressed in terms of an unfettered power. ${ }^{21}$

It follows that the Court will exercise a supervisory function to assess, first, the conformity of the State with its own national law so far as applicable to the interference, and, secondly, to assess that law against more general yardsticks of legality in accordance with international norms. However, the rigour with which this task is undertaken tends to vary somewhat.

In a number of recent cases, the Court has found an interference was not 'prescribed by law' on account of the State's failure to comply with the provisions of its own national law. Thus in Mockute, the applicant's detention on mental health grounds was unlawful as a matter of Lithuanian law, and the Court reasoned that any substantiated interference arising from that detention was thus not prescribed by law. ${ }^{22}$ In Moroz v. Ukraine, the applicant was imprisoned for murder and inter alia complained of the authorities' refusal of visits to the prison chapel. ${ }^{23}$ The Court found that, as a matter of domestic law, it would only have been lawful to restrict such visits to ensure obedience to prison rules or to protect the rights of others. The State had not shown that these conditions had been met, and the restriction was not prescribed by law. ${ }^{24}$ Consideration of this provision of national law allowed an assessment of necessity/proportionality at the "prescribed by law' stage of the analysis. In Nasirov and Others v. Azerbaijan, the Court considered the confiscation of religious materials on the grounds that they had not been authorised for import and the conviction of those in possession of the materials. These interferences were not prescribed by law where there was clear evidence that the religious material had in fact been so authorised. ${ }^{25}$

${ }^{21}$ Gillan v. United Kingdom, 12 January 2010, European Court of Human Rights, Application No. 4158/05, para. 70 .

22 Mockutè v. Lithuania paras. 128 and 130.

23 Moroz v. Ukraine, 2 March 2017, European Court of Human Rights, Application No.5187/07 paras. $91 \mathrm{ff}$.

24 Ibid., paras. 106-107.

25 Nasirov and Others v. Azerbaijan, 20 February 2020, European Court of Human Rights, Application No. 58717/10, paras. 63 and 66. 
Even where an interference is undertaken in accordance with national law, the Court has found that law to be deficient according to the general Convention standards of accessibility, predictability, and non-arbitrariness. The leading case illustrating this approach is Hasan and Chaush v. Bulgar$i a$ in which a branch of the Bulgarian government replaced the Chief Mufti of Bulgarian Muslims and other senior Muslim clerics with the State's choice of leaders. ${ }^{26}$ In respect of the Article 9 complaint, the Court held:

[T] hat in the present case the relevant law does not provide for any substantive criteria on the basis of which the Council of Ministers and the Directorate of Religious Denominations register religious denominations and changes of their leadership in a situation of internal divisions and conflicting claims for legitimacy. Moreover, there are no procedural safeguards, such as adversarial proceedings before an independent body, against arbitrary exercise of the discretion left to the executive [...]. The Court finds, therefore, that the interference with the internal organisation of the Muslim community and the applicants' freedom of religion was not 'prescribed by law' in that it was arbitrary and was based on legal provisions which allowed an unfettered discretion to the executive and did not meet the required standards of clarity and foreseeability. ${ }^{27}$

Another example of this application of higher standards of legality can be found in Güler and Uğurv. Turkey, in which the applicants were convicted for attending a religious service in memory of three members of the Workers' Party of Kurdistan ('PKK') who had been killed by the security forces. ${ }^{28}$ The provision of Turkish criminal law for which the applicants were convicted provided: '[a]nyone who engages in propaganda in favour of a terrorist organisation shall be sentenced to a term of imprisonment of between one and five years'. The Court found that the conviction was not sufficiently foreseeable to be prescribed by law. This was because 'it had not been possible to foresee that mere participation in a religious service would fall within the scope of [the law in question]' ${ }^{29}$

26 Hasan and Chaush v. Bulgaria, 20 October 2000, European Court of Human Rights, Application No. 30985/96.

27 Ibid., paras. 85-86.

28 Güler and Uğur v. Turkey, 2 December 2014, European Court of Human Rights, Nos. 31706/10 and 33088/10.

29 Ibid., para. 55. 
More recently, in Religious Community of Jehovah's Witnesses of Kryvyi Rih's Ternivksy District v. Ukraine, the Court found a local council's refusal to grant a lease to a group of Jehovah's Witnesses to build a place of worship was not prescribed by law. ${ }^{30}$ The refusal was made notwithstanding a domestic court judgment stating that the group met the requirements for such a lease. Although the State contended that refusal was a result of neutral, generally-applicable planning law under which the local council had final discretion, the Court found that the council had 'failed to cite any valid neutral planning-related reason' for the refusal, or for its disregard of the domestic Court. ${ }^{31}$ The council's conduct was therefore considered to be 'arbitrary', and its interference in the community's ability to worship as a group not prescribed by law. ${ }^{32}$

More often than not when the point is raised however, the Court has refused to make rulings relating to the 'prescribed by law' limb, preferring to focus on 'necessity' as a more open-textured and merits-centred way of determining case. Recently examples include Lachiri v. Belgium in which the applicant had argued that the inherently discretionary power of a judge to prohibit her from wearing her headscarf, combined with its inconsistent exercise in practice, created 'uncertainty' about her legal rights and obligations. Here the Court merely passed over this argument, considering it unnecessary to determine in the light of its conclusions on necessity. ${ }^{33}$ In a similar way, the Court refused to consider the contentions of the applicant in Mushfig Mammadov and Others v. Azerbaijan that a provision of law in relation to military conscription was insufficiently precise to be able to predict its applicability to conscientious objectors. The Court reached no view on the matters as it considered its findings on necessity sufficient to determine the application. ${ }^{34}$

30 Religious Community of Jehovah's Witnesses of Kryvyi Rih's Ternivksy District v. Ukraine, 3 September 2019, European Court of Human Rights, Application No. 21477/10.

31 Ibid., paras. 54 and 56.

32 Ibid., para. 57.

33 Lachiri v. Belgium, 18 September 2018, European Court of Human Rights, Application No. 3413/09 (not available in English) paras. 35-36.

34 Mushfig Mammadov and Others v. Azerbaijan, 17 October 2019, European Court of Human Rights, Application Nos. 14604/08, 45823/11, 76127/13, and 41792/15 paras. 80-82. 


\subsection{LEGITIMATE AIM}

Article 9(2) sets out classes of legitimate aim on which a State may rely in order to justify restricting the manifestation of religion or belief: public safety, protection of public order, health or morals, and the rights and freedoms of others. It should be recognised at the outset that the Court's analysis of this requirement is generally of a fairly superficial nature. In practice, the State's argument on legitimate aim will be accepted even if the link between the interference and the aim is questionable. For example, the complaint in Metropolitan Church of Bessarabia and Others v. Moldo$v a$, a case in which Article 9 was ultimately found to have been violated, was against the refusal of the Moldovan authorities to recognise a particular church. ${ }^{35}$ The Court accepted the State's argument that the refusal to grant recognition was intended to protect public safety and public order on the following dubious basis:

At the hearing of 2 October 2001, the Government maintained that it refused to grant the application for recognition submitted by the applicants in order to protect order and public safety. The Moldovan State, the territory of which has oscillated in the course of history between Romania and Russia, has a population that is ethnically and linguistically varied. In these circumstances, there are few factors likely to guarantee the long-term survival of the young Republic of Moldova, which has been independent since 1991. One of these factors is religion, the majority of the population being of the Orthodox Christian religion. In consequence, recognition of the Orthodox Church of Moldova, subordinated to the Patriarchate of Moscow, has enabled the entire population to remain within that Church. Were the applicant Church to be recognised, this cohesion would be in danger of being destroyed, and the Orthodox Christian population would be split between more than one Church; furthermore, there would be political forces at work behind the applicant Church, which is subordinated to the Patriarchate of Bucharest, that were closely connected with Romanian interests favouring reunion between Bessarabia and Romania. Recognition of the applicant Church would therefore revive long-standing rivalries in the population between Russia and Romania, thereby endangering the social peace, and indeed the territorial integrity of Moldova.

35 Metropolitan Church of Bessarabia and Others v. Moldova, 14 December 2001, European Court of Human Rights, Application No. 45701/99. 
The applicants dispute that the impugned measure was intended to protect order and public safety. They allege that the Government has not demonstrated that the applicant Church posed any threat to order and public safety.

The Court considers that States have the power to inquire into whether a movement or association is using supposedly religious aims in order to pursue activities that may harm the population or public safety. In view of the circumstances of the case, the Court holds that the impugned interference did in this case pursue a legitimate aim under Article 9(2) namely the protection of order and public safety. ${ }^{36}$

Moreover, it would seem that the breadth of the concept of legitimate aim is sufficient to absorb almost any justification put forward by a State even if it is not framed in the language of Article 9(2). An example of this is Eweida and Others v. United Kingdom in which, in relation to the first applicant, Ms Eweida, the Court's analysis of the legitimate aim was undertaken as part of its proportionality assessment. ${ }^{37}$ The Court found her company's 'wish to project a certain corporate image' constituted an aim which was 'undoubtedly legitimate' ${ }^{38}$ This conclusion might suggest that projecting a certain corporate image amounts to protecting the rights and freedoms of others, but this is not explicit from the judgment nor is the supposition wholly convincing. The Court's approach did not expressly identify the legitimate aim, nor did it determine what interest the State actually had in internal guidance issued by a private company to its employees. ${ }^{39}$

That said, in the subsequent case of S.A.S. v. France the Court adopted a more rigorous approach to the question of whether the relevant interference pursued a legitimate aim. ${ }^{40}$ This was a challenge to a French law banning face coverings in public places. The Government argued that the prohibition was necessary in the interests of public safety and

36 Ibid., paras. 111-113.

37 Eweida and Others v. United Kingdom, 15 January 2013, European Court of Human Rights, Nos. 38420/10, 59842/10, 51671/10 and 36516/10.

38 Ibid., para. 94.

39 The Court's judgment is animated more by pragmatism than by jurisprudential principle. British Airways had unilaterally revoked the restrictive dress code within weeks in consequence of vocal objection in the media and elsewhere.

40 S.A.S. v. France, 1 July 2014, European Court of Human Rights, Application No. 43835/11. 
'respect for the minimum set out values of an open and democratic society'. ${ }^{41}$ Regarding the second of these aims the Government claimed that there were three values which linked this to the legitimate aim in Article 9(2) of 'protection of the rights and freedoms of others': respect for equality between men and women; respect for human dignity; and respect for the minimum requirements of life in society.

With regard to the first of these, the Court accepted that it could, in theory, constitute a legitimate aim. However, in the facts of this particular case it concluded:

[...] a State Party cannot invoke gender equality in order to ban a practice that is defended by women - such as the applicant - in the context of the exercise of the rights enshrined in those provisions, unless it were to be understood that individuals could be protected on that basis from the exercise of their own fundamental rights and freedoms. ${ }^{42}$

The Court also rejected the Government's second value of human dignity since there was nothing inherently undignified about the covering of the human body, an action about which there are a variety of views. ${ }^{43}$ However, the Court accepted that 'respect for the minimum requirements of life in society' may be properly linked to the legitimate aim of the 'protection of the rights and freedoms of others':

The Court takes into account the respondent State's point that the face plays an important role in social interaction. It can understand the view that individuals who are present in places open to all may not wish to see practices or attitudes developing there which would fundamentally call into question the possibility of open interpersonal relationships, which, by virtue of an established consensus, forms an indispensable element of community life within the society in question. ${ }^{44}$

Here the Court had been faced with persuasive submissions from several high-profile interveners, all of whom argued that the French law

$\begin{array}{ll}{ }_{4} & \text { Ibid., para. } 114 . \\ 42 & \text { Ibid., para. } 119 . \\ { }_{43} & \text { Ibid., para. } 120 . \\ { }_{44} & \text { Ibid., para. } 122 .\end{array}$ 
was in breach of Article $9 .{ }^{45}$ There was therefore considerable pressure on the Court to examine the legitimate aim requirement more thoroughly.

Whether the conclusions the Court reached were satisfactory, and its decision robust, remains to be seen. Its treatment in S.A.S v. France of the aims advanced by France and the manner in which they complied with the Convention have been criticised, even by Strasbourg judges. The reasoning in the case was closely followed in judgments in two conjoined applications: Dakir v. Belgium and Belcacemmi and Oussar v. Belgium. ${ }^{46}$ In justifying a wide-ranging prohibition on the covering of faces, clearly targeted at those worn by some Muslim women, Belgium relied heavily on applying the approach in S.A.S. to the idea that face-to-face interactions were fundamental to 'the establishment of human relations that are essential for living together' and thus social harmony. ${ }^{47}$

Two of the judges, whilst not dissenting, submitted a concurring opinion urging a cautious approach to the precedential use of S.A.S., especially in its consideration of 'legitimate aim' ${ }^{48}$ This was urged for three reasons: (i) the Convention does not provide an 'explicit textual basis' for the 'socalled living together principle as a legitimate aim', and thus whether that principle should fall within the 'protection of rights and freedoms of others' will be heavily fact-dependent; (ii) the 'living together' concept is 'so malleable and unclear that it can potentially serve as a rhetorical tool for regulating any human interaction and behaviour'; and (iii) the idea has overtones of majoritarianism, which could lead to the approbation by the Court of 'government imposed assimilation of human interaction and behaviour'.

The Court indicated in S.A.S v. France a greater willingness to consider applicants' arguments based on legitimate aim. Moreover, though notionally restrictive, S.A.S. makes clear that the categories of legitimate aim set out in Article 9(2) are capable of being malleable, and further debate is inevita-

45 Amnesty International, ARTICLE 19, Human Rights Centre of Ghent University, Liberty, Open Society Justice Initiative.

46 Dakir v. Belgium, 11 July 2017, European Court of Human Rights, Application No. 4619/12; and Belcacemmi and Oussar v. Belgium, 11 July 2017, European Court of Human Rights, Application No. 37798/13.

47 Dakir v. Belgium paras. 31-32, 52, and 56.

48 Ibid., 'Concurring Opinion of Judge Spano joined by Judge Karakaş'. 
ble over the extent of this malleability and the deference that should be paid to a State's own characterisation of the legitimacy of the aim pursued.

\subsubsection{PUBLIC SAFETY AND PUBLIC ORDER}

In the context of Article 10(2), the Court has interpreted 'public order' expansively to mean 'the order that must prevail within the confines of a specific social group [where] disorder in that group can have repercussions on order in society as a whole'. ${ }^{49}$

Where Article 9 is concerned, the legitimate aims of public safety and protection of public order are often found to be applicable at the same time. In Chappell v. United Kingdom restrictions on access to a Druid festival at Stonehenge were found to be justified 'in the interests of public safety, for the protection of public order or for the protection of the rights and freedoms of others'. ${ }^{50}$ Likewise, in Leela Förderkreis v. Germany a campaign designed to raise public awareness of the dangers of certain youth sects was considered to pursue the aims of public safety, public order and the protection of the rights of others. ${ }^{51}$

Examples of cases in which the public order limitation was relied on in isolation (i.e. without public safety) include Serif v. Greece in which a conviction for usurping the functions of a religious minister (which ultimately amounted to a breach of Article 9) was found to be connected to the aim of protecting public order. ${ }^{52}$ The Court appeared to accept the Government's argument that ' $[\mathrm{b}] \mathrm{y}$ protecting the authority of the lawful Mufti the domestic courts sought to preserve order in the particular religious community and in society at large' ${ }^{53}$ Similarly, in $A$. v. Sweden, the Court accepted that a conviction for protesting in public against alcohol and pornography was

49 Engel v. Netherlands, 8 June 1976, European Court of Human Rights, Application No. A/22, para. 98 .

50 Chappell v. United Kingdom, 1 January 1988, European Commission on Human Rights, Application No. 12587/86, para. 1.

51 Leela Förderkreis v. Germany, 6 November 2008, European Court of Human Rights, Application No. 58911/00, para 94.

52 Serif v. Greece, 14 December 1999, European Court of Human Rights, Application No. 38178/97.

53 Ibid., para. 43. 
found to pursue the legitimate aim of public order (and also the protection of the rights and freedoms of others) and ultimately found the complaint to be inadmissible. ${ }^{54}$

\subsubsection{HEALTH AND MORALS}

As for cases in which the Court found the legitimate aim to be protection of health, this is often treated as largely synonymous with public safety. For example, in $X v$. United Kingdom (in which a Sikh motorcycle-driver complained that he was required by law to wear a crash helmet which meant that he was obliged to remove his turban) it was observed:

The Commission considers that the compulsory wearing of crash helmets is a necessary safety measure for motor cyclists. The Commission is of the opinion therefore that any interference that there may have been with the applicant's freedom of religion was justified for the protection of health in accordance with Article 9(2)..$^{55}$

A similar approach was taken in the much more recent case of Eweida v. United Kingdom in which a uniform policy prohibiting nurses from wearing of necklaces was found by the Court to serve the purpose of protecting 'health and safety on a hospital ward'. ${ }^{56}$

Measures seen to protect health may also be considered relevant to public order. This was the case in Cha'are Shalom Ve Tsedek v. France in which an orthodox Jewish association complained that by having to go through ACIP, the only permitted ritual slaughterer, it was being prevented from carrying out ritual slaughter in a manner that was acceptable to its orthodox beliefs. ${ }^{57}$ The Court found no breach of Article 9, with part of this conclusion being based on the fact that the French laws governing the way

54 A. v. Sweden, 1 January 1983, European Commission on Human Rights, Application No. $9820 / 82$.

55 X v. United Kingdom, 12 July 1978, European Commission on Human Rights, Application No. 7992/77.

56 Eweida v. United Kingdom, para. 99.

57 Cha'are Shalom Ve Tsedek v. France, 27 June 2000, European Court of Human Rights, Application No. 27417/95. 
in which animals could be slaughtered pursued the legitimate aims of protecting public health and public order. ${ }^{58}$

\subsubsection{RIGHTS AND FREEDOMS OF OTHERS}

In reality, there will be few interferences with the manifestation of religion or belief which cannot be said to pursue the aim of protecting the rights and freedoms of others. Perhaps unsurprisingly, therefore, the Court has treated this aim as something of a catch-all. For example, it has been found as the underlying purpose for: planning restrictions (along with public order) ${ }^{59}$ compulsory motor insurance, ${ }^{60}$ restrictions on religious dress; ${ }^{61}$ silencing loud religious messages where they were likely to lead to public indignation; ${ }^{62}$ and, the termination of pregnancy when the mother's primary objections to continuing with the pregnancy were described by the court as 'social indications'. ${ }^{63}$

\subsection{NECESSARY IN A DEMOCRATIC SOCIETY}

The delicate balance required by the Convention means that the test of 'necessary in a democratic society' should take on a particular importance. The meaning of 'necessary' in this context was explained in the Article 10 case of Handyside v. United Kingdom:

[...] whilst the adjective 'necessary', within the meaning of [this Article] is not synonymous with 'indispensable', neither has it the flexibility of such expressions as 'admissible', 'ordinary', 'useful', 'reasonable' or 'desirable'. Nevertheless, it is for

58 Ibid., para. 84.

59 Vergos v. Greece, 24 June 2004, European Court of Human Rights, Application No. 65501/01, para. 32 .

${ }^{60}$ Xv. Netherlands, 31 June 1967, European Commission on Human Rights, Application No.2988/66.

${ }^{61}$ Dahlab v. Switzerland, 15 February 2001, European Court of Human Rights, Application No. 2988/66.

${ }^{62}$ X v. Sweden, 5 October 1982, European Court of Human Rights, Application No. $9820 / 82$.

63 H v. Norway, 19 May 1992, European Commission on Human Rights, Application No. $17004 / 90$. 
the national authorities to make the initial assessment of the reality of the pressing social need implied by the notion of 'necessity' in this context. ${ }^{64}$

Not merely is the necessity test a lower threshold than the literal meaning of the word might suggest, it also imports a proportionality assessment:

An instance of interference will be considered 'necessary in a democratic society' for a legitimate aim if it answers a 'pressing social need' and, in particular, if it is proportionate to the legitimate aim pursued and if the reasons adduced by the national authorities to justify it are 'relevant and sufficient'. ${ }^{65}$

Part of the assessment involves balancing the rights of minorities against the community interest, which does itself benefit from pluralism:

Pluralism, tolerance and broadmindedness are hallmarks of a 'democratic society'. Although individual interests must on occasion be subordinated to those of a group, democracy does not simply mean that the views of a majority must always prevail: a balance must be achieved which ensures the fair treatment of people from minorities and avoids any abuse of a dominant position [...]. Pluralism is also built on genuine recognition of, and respect for, diversity and the dynamics of cultural traditions, ethnic and cultural identities, religious beliefs and artistic, literary and socio-economic ideas and concepts. The harmonious interaction of persons and groups with varied identities is essential for achieving social cohesion [...]. Respect for religious diversity undoubtedly represents one of the most important challenges to be faced today; for that reason, the authorities must perceive religious diversity not as a threat but as a source of enrichment. ${ }^{66}$

For example, in Eweida v. United Kingdom it was explained that restrictions on freedom of religion in the workplace should be given weight in the proportionality assessment:

Given the importance in a democratic society of freedom of religion, the Court considers that, where an individual complains of a restriction on freedom of religion

${ }^{64}$ Handyside v. United Kingdom, 7 December 1976, European Court of Human Rights, Application No. A/24, para. 48.

65 Izzetin Doğan and Others v. Turkey, 26 April 2016, European Court of Human Rights, Application No. 62649/10, para. 105.

${ }^{66}$ Ibid., para. 109. 
in the workplace, rather than holding that the possibility of changing job would negate any interference with the right, the better approach would be to weigh that possibility in the overall balance when considering whether or not the restriction was proportionate. ${ }^{67}$

Eweida provides an example of the fact-specific nature of the proportionality test since it was concerned with the conjoined claims of four different applicants, all Christians. ${ }^{68}$ The key issue before the Court was whether restrictions imposed on the manifestation of religion were justified.

The first applicant complained that British Airways' uniform policy, which required any accessory or clothing required for religious reasons to be covered by the uniform unless approval had been given. The effect of this was that the first applicant was prevented from wearing a necklace with a cross on the outside of her uniform so that it was visible to others. The Court concluded that the policy failed to strike a fair balance:

On one side of the scales was Ms Eweida's desire to manifest her religious belief. As previously noted, this is a fundamental right: because a healthy democratic society needs to tolerate and sustain pluralism and diversity; but also because of the value to an individual who has made religion a central tenet of his or her life to be able to communicate that belief to others. On the other side of the scales was the employer's wish to project a certain corporate image. The Court considers that, while this aim was undoubtedly legitimate, the domestic courts accorded it too much weight. Ms Eweida's cross was discreet and cannot have detracted from her professional appearance. There was no evidence that the wearing of other, previously authorised, items of religious clothing, such as turbans and hijabs, by other employees, had any negative impact on British Airways' brand or image. Moreover, the fact that the company was able to amend the uniform code to allow for the visible wearing of religious symbolic jewellery demonstrates that the earlier prohibition was not of crucial importance. ${ }^{69}$

These conclusions can be contrasted with those made in respect of the second applicant, a nurse who was prevented from wearing a necklace with a cross by her hospital's uniform policy which prohibited necklaces to reduce the risk of injury to patients.

\footnotetext{
${ }^{67}$ Eweida v. United Kingdom, para. 83.

68 Ibid.

${ }^{69}$ Ibid., para. 94.
} 
The Court observed that the evidence presented before the domestic Employment Tribunal included the risk that a disturbed patient might seize the chain, thereby injuring herself or the applicant, or that the cross might swing forward and could, for example, come into contact with an open wound. There was also evidence that another Christian nurse had been requested to remove a cross and chain, two Sikh nurses had been told they could not wear a bangle or kirpan, and that flowing hijabs were prohibited. ${ }^{70}$ In the circumstances, the Court concluded that there was no breach of Article 9:

The Court considers that, as in Ms Eweida's case, the importance for the second applicant of being permitted to manifest her religion by wearing her cross visibly must weigh heavily in the balance. However, the reason for asking her to remove the cross, namely the protection of health and safety on a hospital ward, was inherently of a greater magnitude than that which applied in respect of Ms Eweida. Moreover, this is a field where the domestic authorities must be allowed a wide margin of appreciation. The hospital managers were better placed to make decisions about clinical safety than a court, particularly an international court which has heard no direct evidence. ${ }^{71}$

An interesting claim which the Court determined to be admissible, though rejected on its merits, is Church of Jesus Christ of Latter-day Saints v. United Kingdom. ${ }^{72}$ The applicant church complained that the Church of England (and other institutional churches) were afforded an exemption from local taxation of buildings which they were denied, amounting to discrimination in violation of Article 14 taken in conjunction with Article 9. The Government denied that the different treatment amounted to discrimination, and argued that, even if it did, it was objectively justified. 'The exemption,' they contended, 'reflected a policy judgment that the exemption from tax should be based upon a public good, not a private benefit'. ${ }^{73}$

70 Ibid., para. 98.

71 Ibid., para. 99.

72 Church of Jesus Christ of Latter-day Saints v. United Kingdom, 4 March 2014, European Court of Human Rights, Application No. 7552/09.

73 Ibid., para. 17. 
On this issue, the Court gave weight to what it regarded as a material distinction between public and private worship:

Moreover, in the Court's view, any prejudice caused to the applicant Church by the operation of the tax law was reasonably and objectively justified. In this respect, the Court observes that the rates exemption was first conferred on places of public religious worship by the Poor Rate Exemption Act 1833. The purpose of the exemption, as explained by Lord Pearce in the Henning case, was, from the moment it was introduced in 1833, to benefit religious buildings which provided a service to the general public and where the church in question 'worshipped with open doors'. The House of Lords held that there was a public benefit in granting the general public access to religious services. In this regard Lord Scott of Foscote stated that such openness in religious practice could dispel suspicions and contradict prejudices in a multi-religious society [...].

In conclusion, insofar as any difference of treatment between religious groups in comparable situations can be said to have been established in relation to tax exemption of places of worship, such difference of treatment had a reasonable and objective justification. In particular, the contested measure pursued a legitimate aim in the public interest and there was a reasonable relationship of proportionality between that aim and the means used to achieve it. The domestic authorities cannot be considered as having exceeded the margin of appreciation available to them in this context, even having due regard to the duties incumbent on the State by virtue of Article 9 of the Convention in relation to its exercise of its regulatory powers in the sphere of religious freedom. It follows that the Court does not find that the applicant Church has suffered discrimination in breach of Article 14 of the Convention, taken in conjunction with Article 9. ${ }^{74}$

Because the necessity test has become diluted and rolled up into what is often a general and unsophisticated proportionality assessment, there is a tendency for the Court to avoid addressing the full rigour of the limitation provisions of Article 9(2) and instead to take refuge behind the application of the so-called margin of appreciation.

74 Ibid., paras. 32 and 35. 


\section{MARGIN OF APPRECIATION}

The Court's much-maligned 'margin of appreciation' doctrine purports to reflect the principle of subsidiarity in the law of the European Union, whereby the Court affords a degree of deference to the national authorities. This is particularly evident in applying the 'necessary in a democratic society' test. A key decision in the development of this principle is Handyside v. United Kingdom, a case concerning Article 10, in which the Court explained:

The Court points out that the machinery of protection established by the Convention is subsidiary to the national systems safeguarding human rights. The Convention leaves to each Contracting State, in the first place, the task of securing the rights and freedoms it enshrines $[\ldots]$.

These observations apply, notably, to Article 10 (2). In particular, it is not possible to find in the domestic law of the various Contracting States a uniform European conception of morals. The view taken by their respective laws of the requirements of morals varies from time to time and from place to place, especially in our era which is characterised by a rapid and far-reaching evolution of opinions on the subject. By reason of their direct and continuous contact with the vital forces of their countries, State authorities are in principle in a better position than the international judge to give an opinion on the exact content of these requirements as well as on the 'necessity' of a 'restriction' or 'penalty' intended to meet them [...].

Nevertheless, Article 10 (2) does not give the Contracting States an unlimited power of appreciation. The Court, which, with the Commission, is responsible for ensuring the observance of those States' engagements, is empowered to give the final ruling on whether a 'restriction' or 'penalty' is reconcilable with freedom of expression as protected by Article 10. The domestic margin of appreciation thus goes hand in hand with a European supervision. Such supervision concerns both the aim of the measure challenged and its 'necessity' $\left[\ldots . . .^{75}\right.$

75 Handyside v. United Kingdom, paras. 48-49. 


\subsection{WIDE MARGIN OF APPRECIATION WHERE ARTICLE 9 IS CONCERNED}

For the reasons given in Leyla Şahin v. Turkey, the Court tends to afford States a particularly wide margin of appreciation in cases involving Article 9:

Where questions concerning the relationship between State and religions are at stake, on which opinion in a democratic society may reasonably differ widely, the role of the national decision-making body must be given special importance [...]. It is not possible to discern throughout Europe a uniform conception of the significance of religion in society [...]. Rules in this sphere will consequently vary from one country to another according to national traditions and the requirements imposed by the need to protect the rights and freedoms of others [...]. Accordingly, the choice of the extent and form such regulations should take must inevitably be left up to a point to the State concerned, as it will depend on the specific domestic context. ${ }^{76}$

A good example of an Article 9 case in which the Court deployed the margin of appreciation is that of Osmanoğlu and Kocabas v. Switzerland.$^{77}$ The parents of pre-pubescent daughters complained about a rule obliging their girls to take part in mixed swimming lessons at their school (the law only permitted an exemption for pubescent children). Having found that the rule pursued the legitimate aim of protecting the rights and freedoms of others, the Court went on to consider whether it was 'necessary in a democratic society'. The Court observed that Member States enjoy a wide margin of appreciation when it comes to matters concerning the relationship between the State and religion. ${ }^{78}$ In invoking the margin appreciation, the Court attached particular weight to the fact that the swimming lessons were intended to be a shared activity which all the children, regardless of their background or religion, enjoy together. On this basis schools have a particularly important role in ensuring social integration. ${ }^{79}$

76 Leyla Şahin v. Turkey, 10 November 2005, European Court of Human Rights, Application No. 44774/98, para. 109.

77 Osmanoğlu and Kocabaş v. Switzerland, 10 January 2017, European Court of Human Rights, Application No. 29086/12.

78 Ibid., para. 95.

79 Ibid., paras. 96, 98 and 100. 
Moreover, it was thought to be significant that the school had offered to allow the girls to wear a burkini during the lessons and to ensure that they could change their clothes and shower away from the boys. ${ }^{80}$

In less controversial cases the Court has proved willing to find a breach of Article 9 despite an express recognition of the broad margin of appreciation. For example, in Association for Solidarity with Jehovah's Witnesses and Others $v$. Turkey the Court found that planning restrictions on places of religious worship (for a mandatory minimum surface area of 2,500 square metres) violated the Article 9 rights of Jehovah's Witnesses who, as a minority religion in Turkey, only required a small venue to meet and worship. ${ }^{81}$ Despite acknowledging that a broad margin of appreciation was applicable, the Court found that the restrictions were disproportionate. ${ }^{82}$

\subsection{RESTRICTING THE MARGIN OF APPRECIATION?}

From time to time the Court has sought to discourage the overuse of the margin of appreciation. One notable example in recent jurisprudence is the case of Ibragimov v. Russia. ${ }^{83}$ The Court addressed a claim that the respondent State had breached Article 9 and Article 10 (read together) in banning the publication and distribution of books by a Muslim scholar, Said Nursi. Observing that his works had been 'widely available in many countries for decades, including in Russia for at least seven years', the Court went on to comment:

As regards the Government's argument that the State has a wide margin of appreciation in the regulation of interreligious relationships [...], the Court reiterates that a reference to the margin of appreciation afforded to the States to take account of their cultural, historical and religious background is not enough to justify the de-

\footnotetext{
80 Ibid., para. 101.
}

81 Association for Solidarity with Jehovah's Witnesses and Others v. Turkey, 24 May 2016, European Court of Human Rights, Application Nos. 36915/10 and 8606/13.

82 See also İzzettin Doğan v. Turkey in which the Court found that State's discretion on whether to grant official recognition to a small branch of Islam did not fall within the margin of appreciation.

83 Ibragim Ibragimov and Others v. Russia, 28 August 2018, European Court of Human Rights, Application Nos. 1413/08 ad 28621/11. 
nial of access to a universally available important religious text to the population of a single country. ${ }^{84}$

This statement appears to restrict the scope of the margin of appreciation to the justification of interferences in matters which only affect the State concerned, and not interferences in a manifestation of belief which is widely accepted across States. It draws on the opinion of the Court in Akdaş v. Turkey, an Article 10 case in which the applicant was convicted of 'obscene or immoral publication of a character aimed at exciting and exploiting the population's lust' by publishing a translation of Guillaume Apollinaire's erotic novel, 'Les onze mille verges' ${ }^{85}$ Turkey's margin of appreciation was considered incapable of preventing access on the part of the public in Turkey 'to a work amounting to part of the literary patrimony of Europe ${ }^{86}$ which had been published almost a century previously, translated into many different languages, and even 'sanctified by inclusion in «La Pleiade»', ${ }^{87}$

The Court's ruling in Ibragimov ultimately hinged on whether State's courts had provided 'relevant and sufficient reasons' for the prohibiting of the Islamic scholarship in question, and criticised the courts' approach to the issue. The judges' view on the margin of the appreciation is curious. How does it fit with the purpose of the margin of appreciation, which is to allow States a degree of latitude in dealing with issues or tensions that might arise in any State, to reflect the particular context of their society and culture? Leyla Sahin emphasises the moral and societal differences between States as justifying the margin of appreciation, as do recent religious clothing-related cases. In Dakir v. Belgium and Belcacemmi and Oussar v. Belgium, the Court recognised that Belgium in banning religious face-coverings 'sought to address a practice which it deemed incompatible, in Belgian society with [...] the establishment of human relations that are essential for living together' ${ }^{88}$ This essentially moral concept

84 Ibid. para. 103.

85 Akdaş v. Turkey, 16 February 2010, European Court of Human Rights, Application No. 41056/04 (not available in English).

86 Ibid., para. 30 .

87 Ibid., paras. 28-29.

${ }^{88}$ Dakir v. Belgium, para. 56. 
may be unrecognisable and perhaps baffling to people in Muslim-majority States which are parties to the Convention. In the context of Ibragimov, the fact that one religious text may circulate freely in one or more other State should not as a matter of principle restrict another State's ability to regulate that text's circulation.

The second question that Ibragimov poses is: on what basis does the Court have the power or competence to elevate a work, text, or other cultural phenomenon into the category that takes it beyond the reach of legitimate cultural diversity between States? The reasoning in Ibragimov includes a finding as to the importance of a text to a religion, the type of value judgment which the Court has traditionally eschewed, not least because it introduces a high degree of subjectivity into the Court's decision-making. In any event, the attempt by the Court to rein in the margin of appreciation in this way seems somewhat poorly conceived, or at least requires more work to make it convincing. In the meantime, it merely adds to the sense that the margin of appreciation is amorphous and unpredictable, characteristics which ill-become jurisprudential principles.

\section{CONCLUSION}

Since its landmark decision in Kokkinakis the Court has shown greater willingness to examine in great depth the 'prescribed by law' and 'legitimate aim' requirements. States, upon whom the burden of proof lies, have failed to justify interferences in the manifestation of religion and belief to the satisfaction of the Court. Nevertheless, the vast majority of admissible cases turn on the 'necessary in a democratic society' requirement, a classic proportionality assessment which allows a high degree of engagement on the merits of State action, far beyond mere supervision. Just as the Court's analysis has grown more exacting in some respects, it has simultaneously evinced a readiness to deploy the capricious and unpredictable doctrine of margin of appreciation. Thus, instead of a rigorous evaluation of legitimate aim, necessity and proportionality, the Court effectively renders the decision non-justiciable by placing it in the judicial no-man's land of margin of appreciation. 


\section{REFERENCES}

Bratza, Nicolas. 2012. 'The "Precious Asset": Freedom of Religion under the European Convention on Human Rights'. In: Religion and Discrimination Law in the European Union, ed. by Mark Hill, 9-26. Trier: European Consortium for Church and State Research.

Evans, Malcolm. 1997. Religious Liberty and International Law in Europe. Cambridge: Cambridge University Press.

Hill, Mark. 2013. 'Religious Symbolism and Conscientious Objection in the Workplace: An Evaluation of Strasbourg's Judgment in Eweida and others v. United Kingdom'. Ecclesiastical Law Journal 15: 191-203.

\section{KWALIFIKOWANE PRAWO DO WOLNOŚCI RELIGII: ANALIZA OGRANICZEŃ Z ART. 9 EUROPEJSKIEJ KONWENCJI PRAW CZŁOWIEKA}

Streszczenie

Wolność uzewnętrzniania przekonań religijnych zgodnie z art. 9 Europejskiej Konwencji Praw Człowieka nie ma charakteru absolutnego, lecz może być poddana określonym ograniczeniom. Artykuł omawia istotę i zakres tych ograniczeń w świetle orzecznictwa Europejskiego Trybunału Praw Człowieka poczynając od wyroku w sprawie Kokkinakis przeciwko Grecji. Zestawia brzmienie omawianego przepisu Konwencji z jego dość swobodną i niekonsekwentną interpretacją dokonywaną przez Trybunału w Strasburgu. Szczególną uwagę poświęcono następującym kryteriom: „przewidziane przez ustawę”, „konieczne w społeczeństwie demokratycznym”, ,bezpieczeństwo publiczne”, ,porządek publiczny, zdrowie i moralność” oraz ,prawa i wolności innych osób”. Artykuł stawia sobie za cel wyprowadzenie czytelnych zasad z orzecznictwa, w którym nie brak sprzeczności i niejasności, wiążących się szczególnie z przyjmowaną przez Trybunał zwodniczą doktryny marginesu oceny.

Słowa kluczowe: Kokkinakis; wolność religii; art. 9; ograniczenia; porządek publiczny; prawa i wolności innych; przewidziane przez ustawę; konieczne w społeczeństwie demokratycznym; margines oceny; Europejski Trybunał Praw Człowieka; Europejska Konwencja Praw Człowieka 
